\title{
Гендерна складова самооцінки фізичного розвитку школярів 11-13 років
}

\author{
Тетяна Круцевич ${ }^{1}$ \\ Оксана Марченко' \\ Людмила Погасій \\ Ольга Холодова'
}

\begin{abstract}
Національний університет фізичного виховання і спорту України', Київський національний торговельно-економічний університет², Київ, Україна
\end{abstract}

Мета: вивчення особливостей самооцінки фізичного розвитку школярів 11-13 років у гендерному вимірі.

Матеріал і методи: для розв'язання поставлених завдань використовувався комплекс методів дослідження: теоретичні (аналіз, порівняння, узагальнення, систематизація); психолого-діагностичні (опитувальник Є. В. Боченкової «Самоопис фізичного розвитку», тест-опитувальник С. Бем «Маскулінність - фемінінність»); загальноприйняті методи математичної статистики з розрахунком середніх арифметичних величин.

Результати: розглянуто особливості сприйняття свого фізичного розвитку хлопців і дівчат 11-13 років, їх гендерну ідентичність (фемінінність, маскулінність, андрогінність) та визначено вплив гендерної ідентичності школярів на рівень їх загальної самооцінки фізичного розвитку.

Висновки: результати самооцінки фізичного розвитку та фізичної підготовленості школярів дали нам можливість проаналізувати взаємозумовленість загального рівня самооцінки школярів та їх індивідуальних гендерних характеристик. З'ясовано, що на загальну самооцінку в юнаків впливає більше показників, ніж у дівчат. Завищену самооцінку фізичного розвитку мають переважно хлопці - представники маскулінного та андрогінного психологічних типів.

Ключові слова: хлопці, дівчата, самооцінка фізичного розвитку, маскулінність, фемінінність, андрогінність, гендер, фізичне виховання, фізична культура.

\section{Вступ}

Головною метою освітньої політики щодо модернізації фізичного виховання молоді є забезпечення нової якості навчання шляхом впровадження нового змісту, форм і методів навчання школярів у сфері фізичної культури і спорту.

Сьогодні вітчизняний освітній простір вимагає такої наукової парадигми теоретичних пошуків, яка б могла збалансувати гендерну дискримінацію і асиметрію в педагогічному соціумі та досліджувати дійсність із позицій толерантності, гармонізації статево-рольової взаємодії $[21,36]$. Гендерний підхід у сфері фізичної культури і спорту має певні особливості, що робить його окремим напрямком гендерного пізнання структурно-функціональних підходів, згідно з яким усі педагогічні та соціокультурні аспекти у фізичному вихованні молоді можуть мати гендерний вимір [23, 29, 31, 39]. Дослідження питань, пов'язаних із феноменом статі, викликає труднощі не тільки через їх складність та багатомірність, а й через недостатню визначеність та неоднозначність термінів, якими послуговуються вчені. Існування в англомовній літературі понять «sex» i «gender», для яких у нашій мові немає аналогів, призвело до того, що їх трактування не $є$ загальноприйнятим та вимагає авторського самовизначення. При цьому встановлення дефініції термінів «стать» та «гендер» залежить як від професійної належності науковців, так і їх вподобань [1].
Термін «гендер» (gender) використовується в сучасних вітчизняних та західних гуманітарних дослідженнях для означення статі як соціального явища на відміну від суто біологічної статі (sex). Тож стать (sex) є біологічною, а гендер - культурно-символічним визначенням статі [6, 7, 29, 41].

Системний аналіз світового масиву наукових знань та міжнародного досвіду вивчення гендерної проблематики свідчить про те, що на сьогоднішній день, гендерна проблематика у фізичному вихованні стала глибшою за розумінням, ширшою за обсягом сфер ії застосування, крім того, з'явились нові аспекти її реалізації [9, 20, 31, 33, 34 ]. Певні теоретичні напрацювання у висвітленні цього процесу у сфері фізичного виховання відмічаємо у дослідженні І. В. Євстігнєєвої (2012), де вказується, що основними критеріями гендерного виховання учнів основної школи в процесі фізичного виховання є: когнітивний, емоційно-ціннісний, мотиваційний та поведінковий [14]. О.В. Фащук (2011) обґрунтовано особливості ставлення підлітків до уроку фізичної культури з урахуванням гендерної ідентифікації [40]. У праці В.І. Лукащук (2012) зазначено, що спорт, як діяльність, формує андрогінний тип особистості у жінок та призводить до підсилення маскулінності у чоловіків [28]. Гендерні особливості при виборі видів спорту, прояв психофізичних і рухових здібностей юнаків і дівчат вивчали M. Slingerland, L. Haerens, G. Cardon, L. Borghouts (2014) [29, 51, 52, 53]. 
Учені наголошують, що найбільш репрезентативною ознакою підліткового періоду є фундаментальні зміни у сфері самосвідомості, які мають вагоме значення для подальшого розвитку і становлення особистості [5]. Поділяємо беззаперечну думку вчених, які вважають юність не тільки періодом фізичного становлення, а й унікальним етапом когнітивного дорослішання, коли самооцінка хлопців і дівчат значною мірою залежить від стереотипних уявлень про чоловіків і жінок, а диференціація цінностей відбувається відповідно до чоловічих і жіночих стандартів $[5,29,48]$. Проте сьогодні, на жаль, немає ґрунтовних комплексних досліджень самооцінки фізичного розвитку школярів з точки зору впливу гендерної ідентичності, що і визначило актуальність нашого дослідження.

Мета статті - вивчення особливостей самооцінки фізичного розвитку школярів $11-13$ років у гендерному вимірі.

\section{Матеріал і методи дослідження}

Результати дослідження засновані на матеріалах тестування школярів віком 11-13 років (251 респондент: 105 хлопців та 146 дівчат) 33 СО м. Полтави. Процедура наукових досліджень проводилася відповідно до етичних стандартів відповідального комітету з прав людини. Для розв'язання поставлених завдань використовувався комплекс методів:

теоретичні (аналіз, порівняння, узагальнення, систематизація, теоретичне моделювання) проводились $з$ метою узагальнення досвіду науковців, які займаються вивченням проблеми гендерного підходу у навчанні та вихованні, сучасних підходів до розвитку та вдосконалення системи фізичного виховання;

- психолого-діагностичні (опитувальник Є.В. Боченкової «Самоопис фізичного розвитку», тестопитувальник С. Бем «Маскулінність - фемінінність»);
- загальноприйняті методи математичної статистики з розрахунком середніх арифметичних величин (х), середнього квадратичного відхилення (S); розраховувався коефіцієнт кореляції рангів Спірмена. Усі розрахунки виконувалися в програмі SPSS 17.0. Всі дані оброблялись на персональному комп'ютері з використанням пакету стандартних програм (Excel - 2007; Statistica - 10.0).

Наукова робота виконувалась згідно з Планом НДР у галузі фізичної культури і спорту за темою 3.1 «Удосконалення системи педагогічного контролю фізичної підготовленості дітей, підлітків і молоді в закладах освіти» на 2021-2025 рр.

\section{Результати дослідження}

У нашій розвідці важливо встановити особливості сприйняття свого фізичного розвитку у хлопців і дівчат 11-13 років, визначити їх гендерну ідентичність (фемінінність, маскулінність, андрогінність) та розглянути вплив гендерної ідентичності на рівень загальної самооцінки хлопців і дівчат 11-13 років.

Проведені дослідження самооцінки фізичного розвитку хлопців і дівчат 11-13 років показують їх певні розбіжності, які можуть бути пов'язані як із способом життя, так і змістом процесу фізичного виховання у ЗЗСО (табл.1).

Для зіставлення результатів тесту «Самоопис фізичного розвитку» за окремими шкалами ми обрали відносні показники, для цього абсолютні бали перевівши у відсоток від максимального балу (за Є.В. Боченковою).

Отже, в середньому, значення як у хлопців, так і у дівчат складають від 71\% до 86 \% від максимального балу, що взагалі свідчить про дещо завищений рівень уявлень школярів про власний фізичний розвиток та фізичну підготовленість (табл. 1). За середнім балом хлопці 5-го класу найвищі оцінки поставили за такими шкалами: «стрункість тіла» $(97,4$ \% від максимального

Таблиця 1

Середнє значення показників опитувальника "Самоопис фізичного розвитку" (юнаки, дівчата 11-13 років), (\% від максимального бала), (n= 251)

\begin{tabular}{|c|c|c|c|c|c|c|c|c|c|c|c|c|c|}
\hline \multicolumn{2}{|c|}{ 㥕 } & 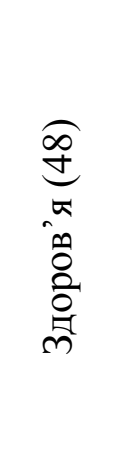 & 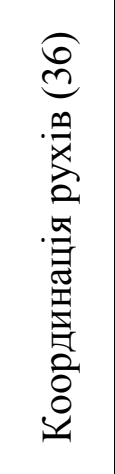 & 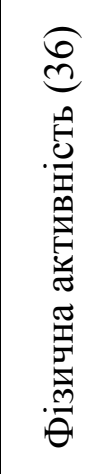 & 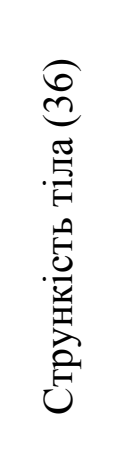 & 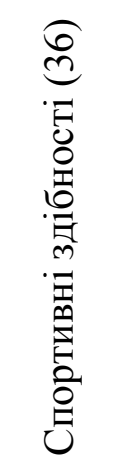 & 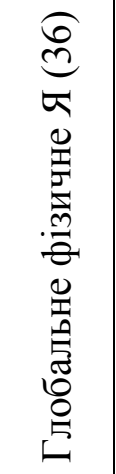 & 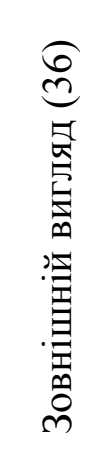 & 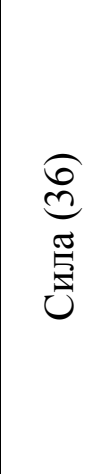 & 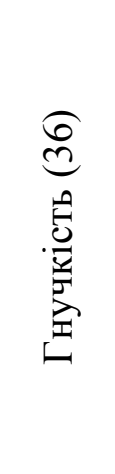 & 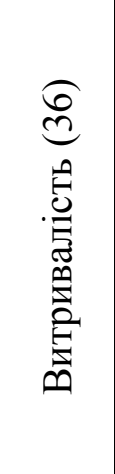 & 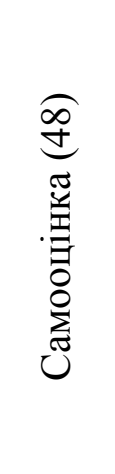 & 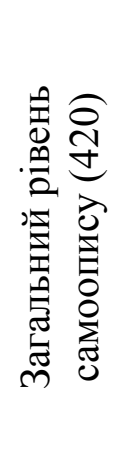 \\
\hline \multirow{2}{*}{ 5кл. } & H & 86,11 & 89,81 & 81,30 & 97,04 & 81,67 & 87,78 & 74,07 & 79,44 & 85,00 & 81,67 & 86,53 & 84,68 \\
\hline & Д & 74,70 & 83,93 & 89,58 & 85,71 & 84,52 & 82,14 & 71,43 & 73,81 & 83,53 & 92,66 & 83,11 & 82,09 \\
\hline \multirow{2}{*}{ бкл. } & ю & 84,96 & 83,11 & 78,50 & 83,00 & 80,89 & 78,00 & 70,78 & 77,22 & 75,00 & 80,28 & 77,67 & 79,17 \\
\hline & д & 82,14 & 85,13 & 78,24 & 76,34 & 79,63 & 81,69 & 76,34 & 74,02 & 75,05 & 69,44 & 81,13 & 78,31 \\
\hline \multirow{2}{*}{ 7кл. } & ю & 82,29 & 82,03 & 75,98 & 79,17 & 80,23 & 80,88 & 74,35 & 76,47 & 74,02 & 81,70 & 82,35 & 79,23 \\
\hline & д & 82,00 & 85,33 & 77,71 & 85,47 & 78,35 & 83,26 & 83,12 & 76,50 & 80,20 & 74,36 & 85,31 & 80,88 \\
\hline
\end{tabular}




\section{СЛОБОЖАНСЬКИЙ НАУКОВО-СПОРТИВНИЙ ВІСНИК}

Таблиця 2

Загальний рівень самооцінки фізичного розвитку школярів (хлопці), n= 105, (\%)

\begin{tabular}{|l|l|l|l|l|l|l|l|}
\hline \multirow{2}{*}{ № } & \multirow{2}{*}{$\begin{array}{l}\text { Загальний } \\
\text { рівень } \\
\text { самооцінки }\end{array}$} & \multicolumn{2}{|c|}{5 клас } & \multicolumn{2}{c|}{6 клас } & \multicolumn{2}{c|}{7 клас } \\
\cline { 2 - 8 } & хлопці & дівчата & хлопці & дівчата & хлопці & дівчата \\
\hline 1 & Завищений & 38,10 & 32,08 & 8,00 & 16,67 & 17,65 & 23,08 \\
\hline 2 & Високий & 61,90 & 43,40 & 74,00 & 59,26 & 58,82 & 58,97 \\
\hline 3 & Середній & 0,00 & 24,07 & 18,00 & 24,07 & 23,53 & 17,95 \\
\hline 4 & Низький & 0,00 & 0,00 & 0,00 & 0,00 & 0,00 & 0,00 \\
\hline
\end{tabular}

балу), «координація рухів» (89,8 \%) та «глобальне фізичне «Я»» $(87,7$ \%). У дівчат 5-го класу «витривалість» отримала найвищий бал (92,6 \%), далі йдуть такі показники: «стрункість тіла» (85,9 \%) та «спортивні здібності» (84,5 \%). Порівнюючи самооцінку фізичного «я» хлопців і дівчат, встановлюємо, що у 5-му та 6-му класах хлопці з одинадцяти показників фізичного розвитку вісім оцінили вищим балом, ніж дівчата. Натомість у 7-му класі ситуація дещо змінилася: практично за всіма шкалами опитувальника самооцінка фізичного розвитку хлопців дорівнює самооцінці дівчат, а за шкалами «глобальне фізичне «Я»», «сила» та «витривалість» стає навіть нижче.

Аналізуючи показники самооцінки розвиненості фізичних якостей та фізичного «Я» хлопців, робимо висновок, що їх фізична підготовленість має слабкий рівень, вони не впевнені у власному зовнішньому вигляді (табл. 1). Найгірші показники у хлопців були позначені за шкалами: «зовнішній вигляд» та «Гнучкість», при цьому, «самооцінка» має один із найвищих показників. Дівчата 11 13 років, оцінюючи власне фізичне «Я», найвищий бал віддали наступним фізичним якостям: «стрункість» (5-й клас: 97,4 \%, 6-й клас: 76,3 \%, 7-й клас: 85,4 \%), «самооцінка» (5-й клас: 83,5 \%, 6-й клас: 81,1\%, 7-й клас: 85,3 \%) та «глобальне фізичне «Я»» (5-й клас: 82,1 \%, 6-й клас: 81,6 \%, 7-й клас: 8,2 \%). При цьому простежується низька фізична активність у 6-7-му класах та занижена оцінка силових здібностей. Шкала «глобальне фізичне «Я»» дає загальну оцінку фізичного стану респондентів, тобто дозволяє отримати сукупні дані про рівень розвитку як власних фізичних якостей і стану здоров'я, так і зовнішнього вигляду. За цією шкалою хлопці та дівчата мають дещо завищену самооцінку.

Порівнюючи самоопис фізичного розвитку хлопців та дівчат, виявляємо, що при низькому рівні фізичної активності та низькій самооцінці фізичних якостей у хлопців завищена загальна самооцінка та показник власного здоров'я. Дівчата 11-13 років при низькій фізичній активності, заниженій оцінці власних фізичних якостей мають занадто високу загальну самооцінку та надто ви- соко оцінюють стрункість свого тіла. Тобто у цьому віці хлопці і дівчата при низькій самооцінці фізичних якостей вважають себе досить привабливими.

Дослідивши показники тесту «Самоопис фізичного розвитку» хлопців і дівчат 11-13 років, використовуючи окрему формулу, ми визначили загальний рівень самооцінки фізичного розвитку та фізичної підготовленості наших респондентів. Отримані результати представлено у таблиці 2.

Таким чином, загальний рівень самооцінки фізичного розвитку хлопців і дівчат 11-13 років має високий та завищений рівень.

На наступному етапі дослідження визначаємо гендерний тип особистості респондентів. Для цього здійснюємо стандартизоване тестування за методикою Сандри Бем «Маскулінність - фемінінність».

Терміни «маскулінність» та «фемінінність» дають нормативні уявлення про психологічні та поведінкові якості, які характерні для чоловіків та жінок та пов'язані з диференціацією статевих ролей [45]. У людини статева диференціація соціально зумовлена. Хлопці та дівчата традиційно відрізняються за характером діяльності: вони виконують різні статеві ролі. Розподіл цих ролей відбувається у дитинстві, він містить не тільки ігри, звичайні для дітей різної статі, але й інші значущі відмінності між хлопцями та дівчатами [13].

Аналіз даних, наведених у таблиці 3 дозволяє констатувати, що кількість андрогінних хлопців у віці 11-13 років (64,92 \%) переважає більше, ніж у три рази кількість маскулінних (20,15 \%) та більше, ніж у четверо - фемінінних $(14,93 \%)$. Натомість кількість андрогінних та фемінінних дівчат із невеликою різницею (4 \%) складає 49,12 \% та 45,03 \%. Утім маскулінних серед них - лише 5,85 \%.

3 метою виявлення взаємозв'язків між загальним рівнем самооцінки респондентів та їх приналежністю до психологічної статі, ми провели порівняльний аналіз показників тесту «самоопис фізичного розвитку» і парамеTpy IS респондентів. Були розглянуті групи респондентів з рівнем самооцінки відносно попадання у відповідний

Таблиця 3

Розподіл загальної кількості респондентів за результатами тесту С. Бем, (n=251)

\begin{tabular}{|l|l|l|l|l|l|}
\hline $\begin{array}{l}\text { Андрогінний } \\
\text { психотип }\end{array}$ & $\begin{array}{l}\text { Маскулінний } \\
\text { психотип }\end{array}$ & $\begin{array}{l}\text { Фемінінний } \\
\text { психотип }\end{array}$ & $\begin{array}{l}\text { Андрогінний } \\
\text { психотип }\end{array}$ & $\begin{array}{l}\text { Маскулінний } \\
\text { психотип }\end{array}$ & $\begin{array}{l}\text { Фемінінний } \\
\text { психотип }\end{array}$ \\
\hline \multicolumn{2}{|l|}{ Хлопці, $11-13$ років, $n=105$} & \multicolumn{2}{|c|}{ Дівчата, $11-13$ років, $n=146$} \\
\hline $64,92 \%$ & $20,15 \%$ & $14,93 \%$ & $49,12 \%$ & $5,85 \%$ & $45,03 \%$ \\
\hline
\end{tabular}


Таблиця 4

Загальний рівень самооцінки фізичного розвитку юнаків різних психологічних типів, $(\mathrm{n}=251)$, \%

\begin{tabular}{|c|c|c|c|c|c|c|}
\hline \multirow{2}{*}{$\begin{array}{c}\text { Загальний рівень } \\
\text { самооцінки }\end{array}$} & \multicolumn{2}{|c|}{$\begin{array}{c}\text { Андрогінний } \\
\text { психологічний тип }\end{array}$} & \multicolumn{2}{c|}{$\begin{array}{c}\text { Маскулінний } \\
\text { психологічний тип }\end{array}$} & \multicolumn{2}{c|}{$\begin{array}{c}\text { Фемінінний } \\
\text { психологічний } \\
\text { тип }\end{array}$} \\
\cline { 2 - 7 } & дівчата & хлопці & дівчата & хлопці & дівчата & хлопці \\
\hline Завищений & 28 & 18 & 4 & 32 & 12 & 22 \\
\hline Високий & 48 & 62 & 64 & 53 & 55 & 54 \\
\hline Середній & 22 & 18 & 32 & 15 & 30 & 24 \\
\hline Низький & 2 & 2 & 0 & 0,00 & 3 & 0,00 \\
\hline Всього & 100 & 100 & 100 & 100 & 100 & 100 \\
\hline
\end{tabular}

кластер (4). Завдяки проведеному дослідженню ми встановили, як впливає психологічний тип особистості на загальний рівень самооцінки фізичного розвитку хлопців і дівчат 11-13 років.

Аналіз результатів свідчить, що у хлопців завищену самооцінку фізичного розвитку мають переважно представники маскулінного психологічного типу. Зауважимо, що серед маскулінних хлопців не виявлено респондентів із заниженою самооцінкою фізичного розвитку. Тобто наявність у людини маскулінних рис характеру може сприяти завищеній самооцінці фізичного розвитку і власних здібностей. У дівчат завищений рівень самооцінки фізичного розвитку мають здебільшого представниці андрогінного психотипу, високий і середній рівень - представниці фемінінного та маскулінного психологічних типів. Хлопці та дівчата, які віднесені до фемінінного гендерного типу, недооцінюють свої здібності (середня самооцінка у $24 \%$ хлопців і $30 \%$ дівчат). Низька самооцінка виявлена тільки у представників фемінінного та андрогінного психологічних типів (табл. 4)

Таким чином, отримані результати наукового експерименту дозволяють припустити, що приналежність респондентів до певного типу гендерної ідентичності має вплив на рівень загальної самооцінки фізичного розвитку.

\section{Висновки / Дискусія}

Науковці стверджують, що самооцінка фізичного розвитку та стану здоров'я $€$ суб'єктивним показником, але ґрунтується на об'єктивних показниках фізичної підготовленості та захворюваності [4, 5, 29, 44]. Від самооцінки особистості залежить формування рівня потреби в досягненнях. Тільки за наявності рефлексії, як внутрішнього стану самоосмислення та розуміння себе, може виховуватися та зміцнюватися самооцінка особистості, її впевненість у собі та самоповага [29]. Психологи слушно зауважують, що у формуванні самоконтролю навчальної діяльності суттєву спонукальну і регуляційну роль виконує самооцінка школярів, яка може проявлятися на різних рівнях: завищеному, високому, низькому, заниженому. Найкращий варіант - це адекватний рівень самооцінки фізичного розвитку, фізичного стану та фізичного здоров'я [27, 29, 34]. Учений Е. Еріксон зазначає, що фізичні якості підлітка, які складають основу фізичного «Я», виступають важливим чинником створення його ідентичності та «Я-концепції» загалом [42]. М. О. Мдівані (1991) передбачив, що «Я-фізичне» має свою власну структуру і зміст [28], проте, у зв'язку з форму- ванням у хлопців та дівчат статево-рольових стереотипів «Я-фізичне» частково може змінюватися.

Виходячи з того, що на формування мотивації до рухової активностішколярів впливає рядвзаємопов'язаних чинників, учені стверджують, що спочатку виникають потреби, а потім формулюється мета. Щоб мета стала дієвою і рушійною силою мають зіграти свою роль зовнішні та внутрішні фактори, які сформують мотивацію до власної програми поведінки людини, котра свідомо обирає той чи інший вид рухової активності відповідно до вподобань, інтересів і бажань і буде активно спрямовувати свою діяльність до означеної мети [32, с. 60]. Самооцінка фізичного розвитку в даному випадку може виступати одним із внутрішніх факторів, який має вплив на формування мотивації до рухової активності. Це говорить про неоднозначність та складність процесу взаємозв'язку внутрішньої сфери особистості та зовнішніх факторів і обставин, які є збудниками до дії, вчинку або діяльності, формуючи належну мотивацію школярів до занять фізичної культурою і спортом [29] .

За результатами отриманих даних самооцінки фізичного розвитку школярів ми встановили, що самооцінку фізичного розвитку хлопці безпосередньо пов'язують зі своєю силою та фізичною активністю, дівчата - із зовнішністю та координацією рухів. Результати самооцінки фізичного розвитку та фізичної підготовленості школярів дали нам можливість проаналізувати взаємозумовленість загального рівня самооцінки школярів та їхніх індивідуальних гендерних характеристик, які ми визначили, застосувавши опитувальник С. Бем «Маскулінність - фемінінність». З'ясовано, що на загальну самооцінку в юнаків впливає більше показників, ніж у дівчат. Завищену самооцінку фізичного розвитку мають переважно хлопці - представники маскулінного та андрогінного психотипів. Тобто наявність у людини чоловічих рис характеру сприяє завищеній самооцінці фізичного розвитку і власних здібностей. У дівчат завищений рівень самооцінки фізичного розвитку мають здебільшого представниці андрогінного психотипу. Занижена самооцінка виявлена тільки у представників фемінінного та андрогінного психологічних типів. У дівчат завищену самооцінку мають більшою мірою представниці андрогінного психотипу. Юнаки і дівчата, які віднесені до фемінінного психотипу, демонструють середню самооцінку або недооцінюють власні здібності.

Підсумовуючи вищезазначене, підкреслимо, що стать людини - складне психічне утворення і трансформуючи освітні завдання, має вплив на особистісні орі- 


\section{СЛОБОЖАНСЬКИЙ НАУКОВО-СПОРТИВНИЙ ВІСНИК}

єнтири, інтереси, вподобання та самооцінку фізичного розвитку школярів, яка формується під впливом різних чинників. I незалежно від того, які судження лежать в основі самооцінки, власні чи інших людей, вона завжди має суб'єктивний характер.

Отже, гендерна складова є однією із складових особистісно-орієнтованого підходу до фізичного виховання школярів, враховує їх індивідуальні особливості у відповідності зі статтю та їх гендерною ідентичністю, дозволяє на цій основі вибір змісту, форм і методів навчання і виховання, створюючи розвивальне освітнє середовище у відповідності з природним потенціалом хлопців і дівчат. Використання гендерних особливостей хлопців і дівчат в теорії і методиці фізичного виховання надає нам широкі можливості для конструктивної взаємодії змісту гендерних досліджень з наявними методиками навчання та концепціями у сфері фізичного виховання

Проведені дослідження не вичерпують проблему вивчення гендерного підходу у фізичному вихованні школярів, а ставлять ряд запитань, які торкаються засобів та методів у фізичному вихованні для формування індивідуальної фізичної культури особистості.

Перспективи подальших досліджень. Подальші наші дослідження будуть присвячені визначенню адекватності самооцінки фізичного розвитку школярів різних вікових груп, а саме - порівнянню результатів тесту «Самоопис фізичного розвитку» з результатами контрольних нормативів по фізичному вихованню.

Конфлікт інтересів. Автори заявляють, що відсутній конфлікт інтересів, який може сприйматись таким, що може завдати шкоди неупередженості статті.

Джерела фінансування. Ця стаття не отримала фінансової підтримки від державної, громадської або комерційної організації.

\section{Список посилань}

1. Арканцева Т. А. (2011), Отношение родителей и детей в гендерном измерении: учеб. пособ. Москва: НОУ ВПО Московский психолого-социальный ин-т, 70 с.

2. Бендас Т. В. (2009), Гендерная психология: учеб. пособ. Санкт-Петербург: Питер Пресс, 428 с.

3. Бем С. (2004), Линзы гендера: трансформация взгляда на проблему первенства полов. Москва, 336 с.

4. Боченкова Е. В. (2000), Самоописание физического развития: метод. пособ. Краснодар: КГАФК, 26 с.

5. Булах І. С. (2004), Психологічні основи особистісного зростання підлітків: автореферат. Київ: Нац пед. ун-т ім. М.П. Драгоманова, $42 \mathrm{c}$.

6. Ворожбитова А. Л. (2011), Гендер в спортивной деятельности: учеб. пособ. Москва: ФЛИНТА, 216 с.

7. Гендерні питання. Проблеми освіти (2004): наук.-метод. зб. Вип. 36. Київ: Наук.-метод. центр вищої освіти, 172 с.

8. Гіденс Е. (1999), Соціологія. К.: Основи, 726 с.

9. Голощапов Б. Р. (2005), Історія фізичної культури і спорту. М.: Академія, 312 с.

10. Григоревич В. В. (2008), Загальна історія фізичної культури. М.: Радянський спорт, 228 с.

11. Грошев И. В. (2005), Психофизиологические различия мужчин и женщин. М. : Издательство Московского психологосоциального института. Воронеж: Издательство НПО «МОДЕК», 464 с.

12. Дамадаеева А. С. (2010), «Специфика гендерной дифференциации личности в спорте». Ученые записки университета им. П.Ф. Лесгафта. №10(68). С. 54

13. Дульмухаметова Г. Ф. (2011), Педагогические условия половой дифференциации обучения младших школьников: диссертация. Казань: Татарский гос. гуманитарно-педагогический ун-т, 245 с.

14. Євстігнєєва І. В. (2012), Гендерне виховання учнів основної школи на уроках фізичної культури: автореферат. Луганськ, 24 с.

15. Закон України «Про забезпечення рівних прав та можливостей жінок і чоловіків». Відомості Верховної Ради, $2018,(5): 35$.

16. Ильин Е. П. (2010), Пол и гендер. Санкт-Петербург: Питер, 686 с.

17. Кікінежді О. М. (2009), «Шляхи розвитку ґендерної культури сучасного вчителя», Вісник післядипломної освіти: збірник наукових праць / Ун-т менедж. освіти АПН України, Асоц. безперерв.освіти дорослих; редкол.: О. Л. Онуфрієва та ін.; голов.ред. В. В. Олійник. К.: Геопринт, Ч.2. С.137-146.

18. Клецина И. С. (2004), Психология гендерных отношений: теория и практика. Санкт-Петербург: Алтейя, 408 с.

19. Клецина И. С. (2001), «О проблемах гендерной психологии», Мир психологии, № 4, С. 162-208.

20. Ковальчук Л. О. (2008), Гендерне виховання учнівської молоді в Німеччині: дисертація. Тернопіль: Тернопільський нац. пед. ун-т ім. Володимира Гнатюка.

21. Круцевич Т. Ю., Марченко О. Ю. (2019), «Історичні засади формування гендерного підходу у фізичному вихованні», Фізичне виховання, спорт і культура здоров'я у сучасному суспільстві. № 4 (44), С. 26-34.

22. Круцевич Т. Ю., Марченко О. Ю. (2020), «Вплив занять спортом на формування маскулінних та фемінінних рис характеру у школярів різних вікових груп», Фізичне виховання, спорт і культура здоров'я у сучасному суспільстві, № 1 (49), С. 74-89.

23. Круцевич Т. Ю. (2017), Теорія і методика фізичного виховання: підруч. для студ. вищ. навч. закл. фіз. виховання і спорту. Т. 2. Київ: Олімпійська літ. 392 с.

24. Круцевич Т. Ю., Марченко О. Ю. (2020), «Концептуальні підходи в дослідженнях гендерної диференціації у фізичному вихованні», Теорія і методика фізичного виховання і спорту, № 2, С. 80-87.

25. Круцевич Т. Ю., Марченко О. Ю. (2019), «Концептуальні засади гендерного підходу у фізичному вихованні школярів», Спортивний вісник Придніпров'я, № 2, С. 104-114.

26. Круцевич Т. Ю., Марченко О. Ю. (2015), «Гендерні особливості самоопису фізичного розвитку школярів», Педагогіка, психологія та медико-біологічні проблеми фіз. виховання і спорту, № 12, С. 56-60.

27. Круцевич Т. Ю., Марченко О. Ю. (2021), «Особливості та відмінності самооцінки фізичного розвитку та фізичного здоров'я юнаків міської та сільської місцевості», Науковий часопис Національного педагогічного університету імені М. П. Драгоманова. Серія 15: Науково-педагогічні проблеми фізичної культури (фізична культура і спорт), № 5К(134), С. 85-89.

28. Мдивани М. О. (1991), Исследование структуры физического образа «я» у школьников: автореферат. Москва, 24 с.

29. Марченко О. Ю. (2018), Теоретико-методологічні основи гендерного підходу до формування аксіологічної значущості фізичної культури школярів: монографія. Переяслав-Хмельницький, 292 с. 
30. Марченко О. (2018), «Характерні відмінності у виборі факторів здорового способу життя як складових індивідуальної фізичної культури сучасних школярів», Слобожанський науково-спортивний вісник, № 6(68), С. 10-15.

31. Марченко О. Ю. (2019), Теоретико-методологічні основи гендерного підходу до формування аксіологічної значущості фізичної культури у школярів: автореферат. Київ: Нац. ун-т фіз. вихованя і спорту України, 45 с.

32. Пангелова Н. Є., Круцевич Т. Ю., Данилко В. М. (2018), Теоретико-методичні основи оздоровчої фізичної культури: навч. посіб. Переяслав-Хмельницький, 454 с.

33. Пушкарева Н. Л. (2001), «Гендерные исследования: рождение, становление, методы и перспективы в системе исторических наук», Женщина. Гендер. Культура. Москва, С. 21.

34. Практикум по гендерной психологии (2003) / Под ред. И.С. Клециной. СПб.: Питер, 479 с.

35. Самойленко Н. І. (2016), «Передумови виникнення гендерного підходу у педагогічній науці», Молодий вчений, №6(33), С. 458 - 461

36. Саух П. Ю. (2011), Інновації у вищій освіті: проблеми, досвід, перспективи. Житомир: Вид-во ЖДУ ім. Івана Франка, 444 с.

37. Тарасенко Л. В. (2007), Гендерный подход в физическом воспитании как фактор оздоровления младших школьников: диссертация. Тула: Тульский гос. пед. ун-т им. Л.Н. Толстого, 183 с.

38. Татаринцева Н. Е. (1999), Педагогические условия воспитания основ полоролевого поведения детей младшего дошкольного возраста: автореферат. Ростов-на-Дону, 18 с.

39. Томенко О. А. (2012), Неспеціальна фізкультурна освіта учнівської молоді: теорія і методологія: монографія. Суми: Вид-во «МакДен», 276 с.

40. Фащук О. В. (2011), Гендерні особливості фізичного виховання підлітків: автореферат. Івано-Франківськ: Прикарпатський нац. ун-т ім. Василя Стефаника, С.15

41. Штылева Л. В. (2001), Гендерный подход в дошкольной педагогике: теория и практика. Мурманск, С. 40-47.

42. Эриксон Э. Г. (2006), Ідентичність: юність і криза. Москва: МПСІ, 352 с.

43. Andrii Sitovskyi, Borys Maksymchuk, Vasyl Kuzmenko, Yuliya Nosko, Zoryana Korytko, Olga Bahinska, Oksana Marchenko (2019), "Differentiated approach to physical education of adolescents with different speed of biological development", Journal of Physical Education and Sport, Vol.19 (3), Art 222, pp. 1532 - 1543.

44. Bem S. L. (1983), «Gender schema theory and its implications for child development: Raising gender - schematic chidren in a gender - schematic society», Journal of women in culture and society, №8(4), pp. 65-78.

45. Crum B., Mester J. (1994), A critical review of competing PE concepts. Sport scinces in Europe 1993 - Current and future perspectives. Aachen: Meyer and Meyer, pp. 516-533.

46. Krutsevych Т. Ү., Marchenko О. Ү. (2017), «Age differenced of self-esteem of physical self at school. Gender aspects», Фізичне виховання, спорт і культура здоров'я у сучасному суспільстві, № 2(38), pp. 112-116.

47. Krutsevych T., Turchyk Y., Lukianchenko M., Djatlenko S. (2010), «The peculiariarities of physical education program in Ukraine», European J. of Physical and Health Education, №5, pp. 16-21.

48. Scott S. (1986), «Gender: a useful category of historical analisis», The American Historical Review, № 5, pp. 10-67.

49. Slingerland M., Haerens L., Cardon G., Borghouts L. (2014), «Differences in perceived competence and physical activity levels during single gender modified basketball game playin middleschool physical education", European Physical Education Review, № 20, pp. 20-35.

Стаття надійшла до редакції: 02.11.2021 р.

Опубліковано: 23.12.2021 p.

Аннотация. Татьяна Круцевич, Оксана Марченко, Людмила Погасий, Ольга Холодова. Гендерная составляющая самооценки физического развития школьников 11-13 лет. Цель: исследование особенностей самооценки физического развития школьников 11-13 лет в гендерном измерении. Материал и методы: для решения поставленных задач использовался комплекс методов исследования: теоретические (анализ, сравнение, обобщение, систематизация); психолого-диагностические (опросник Е. В. Боченковой “Самоописание физического развития», тест-опросник С. Бем «Маскулинность - фемининность»); общепринятые методы математической статистики с расчетом средних арифметических величин. Результаты: рассмотрены особенности восприятия своего физического развития юношей и девушек 11-13 лет, их гендерная идентичность (фемининность, маскулинность, андрогинность) и определено влияние гендерной идентичности школьников на уровень их общей самооценки физического развития. Выводы: результаты самооценки физического развития и физической подготовленности школьников позволили нам проанализировать взаимообусловленность общего уровня самооценки школьников и их индивидуальных гендерных характеристик. Выяснено, что на всеобщую самооценку у юношей влияет больше показателей, чем у девушек. Завышенную самооценку физического развития имеют преимущественно ребята - представители маскулинного и андрогинного психологических типов.

Ключевые слова: ребята, девушки, самооценка физического развития, маскулинность, фемининность, андрогинность, гендер, физическое воспитание, физическая культура.

Abstract. Tetyana Krutsevych, Oksana Marchenko, Liudmyla Pohasii, Olga Kholodova. Gender component of selfassessment of physical development of schoolchildren aged 11-13. Purpose: to study of the peculiarities of self-assessment of physical development of schoolchildren aged 11-13 in the gender dimension. Material and methods: a set of research methods was used to solve the set tasks: theoretical (analysis, comparison, generalization, systematization); psychological-diagnostic (EV Bochenkova's questionnaire "Self-description of physical development», S. Bem's test-questionnaire "Masculinity - femininity»); generally accepted methods of mathematical statistics with the calculation of arithmetic means. Results: considers the peculiarities of the perception of their physical development of boys and girls 11-13 years, their gender identity (femininity, masculinity, androgyny) and identifies the impact of gender identity of students on the level of their overall self-esteem of physical development. Conclusions: the results of self-assessment of physical development and physical fitness of students gave us the opportunity to analyze the interdependence of the general level of self-esteem of students and their individual gender characteristics. It was found that the overall self-esteem of boys is influenced by more indicators than that of girls. Inflated self-esteem of physical development is mainly boys - representatives of masculine and androgynous psychological types.

Keywords: boys, girls, self-assessment of physical development, masculinity, femininity, androgyny, gender, physical education, physical culture. 


\section{References}

1. Arkantseva, T. A. (2011), Otnosheniye roditeley i detey $v$ gendernom izmerenii [The attitude of parents and children in the gender dimension]: ucheb. posob. Moskva: NOU VPO Moskovskiy psikhologo-sotsial'nyy in-t, 70 p. (in Russ.).

2. Bendas, T. V. (2009), Gendernaya psikhologiya [Gender psychology]: ucheb. posob. Sankt-Peterburg: Piter Press, 428 p. (in Russ.).

3. Bem, S. (2004), Linzy gendera: transformatsiya vzglyada na problemu pervenstva polov [The Lenses of Gender: Transformation of the View on the Problem of Gender Primacy]. Moskva, 336 p. (in Russ.).

4. Bochenkova, Ye. V. (2000), Samoopisaniye fizicheskogo razvitiya [Self-description of physical development]: metod. posob. Krasnodar: KGAFK, 26 p. (in Russ.).

5. Bulakh, I. S. (2004), Psykholohichni osnovy osobystisnoho zrostannya pidlitkiv [Psychological foundations of personal growth of adolescents]: avtoreferat. Kyyiv: Nats ped. un-t im. M.P. Drahomanova, 42 p. (in Ukr.)

6. Vorozhbitova, A. L. (2011), Gender v sportivnoy deyatel'nosti [Gender in sports activity]: ucheb. posob. Moskva: FLINTA, 216 p. (in Russ.).

7. Henderni pytannya. Problemy osvity [Gender issues. Problems of education] (2004): nauk.-metod. zb. Vyp. 36. Kyyiv: Nauk.metod. tsentr vyshchoyi osvity, 172 p. (in Ukr.)

8. Hidens, E. (1999), Sotsiolohiya [Sociology]. K.: Osnovy, 726 p. (in Ukr.)

9. Holoshchapov, B. R. (2005), Istoriya fizychnoyi kul'tury i sportu [History of Physical Culture and Sports]. M.: Akademiya, 312 p. (in Ukr.)

10. Hryhorevych, V. V. (2008), Zahal'na istoriya fizychnoyi kul'tury [General history of physical culture]. M.: Radyans'kyy sport, 228 p. (in Ukr.)

11. Groshev, I. V. (2005), Psikhofiziologicheskiye razlichiya muzhchin i zhenshchin [Psychophysiological differences between men and women] M.: Izdatel'stvo Moskovskogo psikhologo-sotsial'nogo instituta. Voronezh: Izdatel'stvo NPO «MODEK», 464 p. (in Russ.).

12. Damadayeeva, A. S. (2010), «Specificity of gender differentiation of personality in sports», Uchenyye zapiski universiteta im. P.F. Lesgafta. №10(68). P. 54. (in Russ.).

13. Dul'mukhametova, G. F. (2011), Pedagogicheskiye usloviya polovoy differentsiatsii obucheniya mladshikh shkol'nikov [Pedagogical conditions of gender differentiation in teaching younger schoolchildren]: dissertatsiya. Kazan': Tatarskiy gos. gumanitarnopedagogicheskiy un-t, 245 p. (in Russ.).

14. Yevstihnyeyeva, I. V. (2012), Henderne vykhovannya uchniv osnovnoyi shkoly na urokakh fizychnoyi kul'tury [Gender education of primary school students in physical education lessons]: avtoreferat. Luhans'k, 24 p. (in Ukr.)

15. Zakon Ukrayiny «Pro zabezpechennya rivnykh prav ta mozhlyvostey zhinok i cholovikiv». Vidomosti Verkhovnoyi Rady, 2018, (5):35. (in Ukr.)

16. Il'in Ye. P. (2010), Pol i gender. Sankt-Peterburg: Piter, 686 p. (in Russ.).

17. Kikinezhdi, O. M. (2009), «Ways of development of gender culture of the modern teacher», Visnyk pislyadyplomnoyi osvity: zbirnyk naukovykh prats' / Un-t menedzh. osvity APN Ukrayiny, Asots. bezpererv.osvity doroslykh; redkol.: O. L. Onufriyeva ta in.; holov. red. V. V. Oliynyk. K.: Heoprynt, CH.2. pp.137-146. (in Ukr.)

18. Kletsina, I. S. (2004), Psikhologiya gendernykh otnosheniy: teoriya i praktika [Psychology of gender relations: theory and practice]. Sankt-Peterburg: Alteyya, 408 p. (in Russ.).

19. Kletsina, I. S. (2001), "On the Problems of Gender Psychology», Mir psikhologii, № 4, pp. 162-208. (in Russ.).

20. Koval'chuk, L. O. (2008), Henderne vykhovannya uchnivs'koyi molodi v Nimechchyni [Gender education of student youth in Germany]: dysertatsiya. Ternopil': Ternopil's'kyy nats. ped. un-t im. Volodymyra Hnatyuka. (in Ukr.)

21. Krutsevych, T. Yu., Marchenko, O. Yu. (2019), «Historical principles of forming a gender approach in physical education», Fizychne vykhovannya, sport i kul'tura zdorov'ya u suchasnomu suspil'stvi. № 4 (44), pp. 26-34. (in Ukr.)

22. Krutsevych, T. Yu., Marchenko, O. Yu. (2020), "The impact of sports on the formation of masculine and feminine traits in students of different ages», Fizychne vykhovannya, sport i kul'tura zdorov'ya u suchasnomu suspil'stvi, № 1 (49), pp. 74-89. (in Ukr.)

23. Krutsevych, T. Yu. (2017), Teoriya i metodyka fizychnoho vykhovannya [Theory and methods of physical education]: pidruch. dlya stud. vyshch. navch. zakl. fiz. vykhovannya i sportu. T. 2. Kyyiv: Olimpiys'ka lit. 392 p. (in Ukr.)

24. Krutsevych, T. Yu., Marchenko, O. Yu. (2020), "Conceptual approaches in the study of gender differentiation in physical education», Teoriya i metodyka fizychnoho vykhovannya i sportu, № 2, pp. 80-87. (in Ukr.)

25. Krutsevych, T. Yu., Marchenko, O. Yu. (2019), "Conceptual principles of gender approach in physical education of schoolchildren», Sportyvnyy visnyk Prydniprov'ya, № 2, pp. 104-114. (in Ukr.)

26. Krutsevych, T. Yu., Marchenko, O. Yu. (2015), «Gender features of self-description of physical development of schoolchildren», Pedahohika, psykholohiya ta medyko-biolohichni problemy fiz. vykhovannya i sportu, № 12, pp. 56-60. (in Ukr.)

27. Krutsevych, T. Yu., Marchenko, O. Yu. (2021), «Features and differences of self-assessment of physical development and physical health of young people in urban and rural areas", Naukovyy chasopys Natsional'noho pedahohichnoho universytetu imeni M. P. Drahomanova. Seriya 15: Naukovo-pedahohichni problemy fizychnoyi kul'tury (fizychna kul'tura i sport), № 5K(134), pp. 85-89. (in Ukr.)

28. Mdivani, M. O. (1991), Issledovaniye struktury fizicheskogo obraza «YA» u shkol'nikov [Study of the structure of the physical image «l» in schoolchildren]: avtoreferat. Moskva, 24 p. (in Russ.).

29. Marchenko, O. Yu. (2018), Teoretyko-metodolohichni osnovy hendernoho pidkhodu do formuvannya aksiolohichnoyi znachushchosti fizychnoyi kul'tury shkolyariv [Theoretical and methodological foundations of the gender approach to the formation of axiological significance of physical culture of schoolchildren]: monohrafiya. Pereyaslav-Khmel'nyts'kyy, 292 p. (in Ukr.)

30. Marchenko, O. (2018), "Characteristic differences in the choice of factors of a healthy lifestyle as components of individual physical culture of modern schoolchildren», Slobozhans'kyy naukovo-sportyvnyy visnyk, № 6(68), pp.10-15. (in Ukr.)

31. Marchenko, O. Yu. (2019), Teoretyko-metodolohichni osnovy hendernoho pidkhodu do formuvannya aksiolohichnoyi znachushchosti fizychnoyi kul'tury u shkolyariv [Theoretical and methodological foundations of a gender approach to the formation of axiological significance of physical culture in schoolchildren]: avtoreferat. Kyyiv: Nats. un-t fiz. vykhovanya i sportu Ukrayiny, 45 p. (in Ukr.)

32. Panhelova, N. Ye., Krutsevych, T. Yu., Danylko, V. M. (2018), Teoretyko-metodychni osnovy ozdorovchoyi fizychnoyi kul'tury [Theoretical and methodological foundations of health physical culture]: navch. posib. Pereyaslav-Khmel'nyts'kyy, 454 p. (in Ukr.)

33. Pushkareva, N. L. (2001), "Gender Studies: Birth, Formation, Methods and Prospects in the System of Historical Sciences», Zhenshchina. Gender. Kul'tura. Moskva, P. 21. (in Russ.).

34. Praktikum po gendernoy psikhologii [Workshop on Gender Psychology] (2003) / Pod red. I.S. Kletsinoy. SPb.: Piter, 479 p. (in Russ.).

35. Samoylenko, N. I. (2016), «Prerequisites for the emergence of a gender approach in pedagogical science», Molodyy vchenyy, №6(33), pp. 458 - 461. (in Ukr.) 
36. Saukh, P. Yu. (2011), Innovatsiyi u vyshchiy osviti: problemy, dosvid, perspektyvy [Innovations in higher education: problems, experience, prospects]. Zhytomyr: Vyd-vo ZHDU im. Ivana Franka, 444 p. (in Ukr.)

37. Tarasenko, L. V. (2007), Gendernyy podkhod v fizicheskom vospitanii kak faktor ozdorovleniya mladshikh shkol'nikov [Gender approach in physical education as a factor in the health improvement of younger schoolchildren]: dissertatsiya. Tula: Tul'skiy gos. ped. un-t im. L.N. Tolstogo, 183 p. (in Russ.).

38. Tatarintseva N. Ye. (1999), Pedagogicheskiye usloviya vospitaniya osnov polorolevogo povedeniya detey mladshego doshkol'nogo vozrasta [Pedagogical conditions for the upbringing of the foundations of sex-role behavior in children of primary preschool age]: avtoreferat. Rostov-na-Donu, 18 p. (in Russ.).

39. Tomenko, O. A. (2012), Nespetsial'na fizkul'turna osvita uchnivs'koyi molodi: teoriya i metodolohiya [Non-special physical education of student youth: theory and methodology]: monohrafiya. Sumy: Vyd-vo «MakDen», 276 p. (in Ukr.)

40. Fashchuk, O. V. (2011), Henderni osoblyvosti fizychnoho vykhovannya pidlitkiv [Gender features of physical education of adolescents]: avtoreferat. Ivano-Frankivs'k: Prykarpat•s'kyy nats. un-t im. Vasylya Stefanyka, P.15. (in Ukr.)

41. Shtyleva, L. V. (2001), Gendernyy podkhod v doshkol'noy pedagogike: teoriya i praktika [Gender approach in preschool pedagogy: theory and practice]. Murmansk, pp. 40-47. (in Russ.).

42. Йrykson, Й. Н. (2006), Identychnist': yunist' i kryza [Identity: youth and crisis]. Moskva: MPSI, 352 p. (in Russ.).

43. Andrii Sitovskyi, Borys Maksymchuk, Vasyl Kuzmenko, Yuliya Nosko, Zoryana Korytko, Olga Bahinska, Oksana Marchenko (2019), «Differentiated approach to physical education of adolescents with different speed of biological development», Journal of Physical Education and Sport, Vol.19 (3), Art 222, pp. 1532 - 1543. (in Eng.).

44. Bem S. L. (1983), «Gender schema theory and its implications for child development: Raising gender - schematic chidren in a gender - schematic society», Journal of women in culture and society, №8(4), pp. 65-78. (in Eng.).

45. Crum B., Mester J. (1994), A critical review of competing PE concepts. Sport scinces in Europe 1993 - Current and future perspectives. Aachen: Meyer and Meyer, pp. 516-533. (in Eng.).

46. Krutsevych Т. Ү., Marchenko О. Ү. (2017), «Age differenced of self-esteem of physical self at school. Gender aspects», Фізичне виховання, спорт і культура здоров'я у сучасному суспільстві, № 2(38), pp. 112-116. (in Eng.).

47. Krutsevych T., Turchyk Y., Lukianchenko M., Djatlenko S. (2010), «The peculiariarities of physical education program in Ukraine», European J. of Physical and Health Education, №5, pp. 16-21. (in Eng.).

48. Scott S. (1986), "Gender: a useful category of historical analisis», The American Historical Review, № 5, pp. 10-67. (in Eng.).

49. Slingerland M., Haerens L., Cardon G., Borghouts L. (2014), «Differences in perceived competence and physical activity levels during single gender modified basketball game playin middleschool physical education", European Physical Education Review, № 20, pp. 20-35. (in Eng.).

Received: 02.11.2021.

Published: 23.12.2021

\section{Відомості про авторів / Information about the Authors}

Круцевич Тетяна Юріївна: доктор наук з фізичного виховання і спорту, професор; Національний університет фізичного виховання і спорту України: вул. Фізкультури, 1, Київ, Україна, 03150.

Круцевич Татьяна Юрьевна: доктор наук по физическому воспитанию и спорту, профессор; Национальный университет физического воспитания и спорта Украины: ул. Физкультуры, 1, Киев, Украина, 03150.

Tetyana Krutsevych: Doctor of Science (Physical Education and Sport), Professor; National University of Physical Education and Sport of Ukraine: Fizkultury street, 1, Kyiv, Ukraine, 03150.

ORCID: https://orcid.org/0000-0002-4901-6148

E-mail: tmfv@ukr.net

Марченко Оксана Юріївна: доктор наук з фізичного виховання і спорту, професор; Національний університет фізичного виховання і спорту України: вул. Фізкультури 1, м. Київ, Україна, 03150.

Марченко Оксана Юрьевна: доктор наук по физическому воспитанию и спорту, профессор; Национальный университет физического воспитания и спорта Украины: ул. Физкультуры, 1, г. Киев, Украина, 03150.

Oksana Marchenko: Doctor of Science (Physical Education and Sport), Professor; National University of Physical Education and Sport of Ukraine: Fizkultury street, 1, Kyiv, Ukraine, 03150.

ORCID: https://orcid.org/0000-0002-2902-5960

E-mail: o.mar4enko17@gmail.com

Погасій Людміла Іванівна: старший викладач кафедри фізичної культури; Київський національний торгівельно-економічний університет: вул. Кіото, 19, Київ, Україна, 02156.

Погасий Людмила Ивановна: старший преподаватель кафедры физической культуры; Киевский Национальный торговоэкономический университет: ул. Киото, 19, Киев, Украина, 02156.

Liudmyla Pohasii: senior lecturer of the Department of Physical Culture; Kyiv National University of Trade and Economics: street Kyoto, 19, Kyiv, Ukraine, 02156.

ORCID: https://orcid.org/0000-0003-2546-922X

E-mail: knteusport@ukr.net

Холодова Ольга Святозарівна: к. фіз.вих., доцент; Національний університет фізичного виховання і спорту України: вул. Фізкультури 1, м. Київ, Україна, 03150.

Холодова Ольга Святозаровна: к.физ.восп., доцент; Национальный университет физического воспитания и спорта Украины: ул. Физкультуры, 1, Киев, Украина, 03150.

Olga Kholodova: Phd (Physical Education and Sport), Associate Professor; National University of Physical Education and Sport of Ukraine: Fizkultury street, 1, Kyiv, Ukraine, 03150.

ORCID: https://orcid.org/0000-0002-4217-0548

E-mail: holodova2007@ukr.net 